\title{
THE FOOD LOSSES AND FOOD WASTE IT'S IMPACT AND INITIATIVES ON ENVIRONMENTAL MANAGEMENT IN THE SLOVAK REPUBLIC
}

\section{Zuzana KAPSDORFEROVÁ; Petronela ŠVIKRUHOVÁ; Mária DOBIŠOVÁ; Mária MEDVEĎOVÁ}

Slovak University of Agriculture in Nitra, Faculty of Economics and Management, Department of Management

\begin{abstract}
Although there are no accurate data in the world on food losses and waste, according to the FAO, globally about one third of the food produced is lost or degraded as waste along the food chain, from production to consumption. The large scale of food losses and waste leads responsible politicians and strong economic players not to see this as a coincidence, but as an integral part of food systems. Successful reduction of food losses and food waste will save natural resources for future generations and has the potential to improve food security and nutrition by meeting the goals of the Agenda 2030 on Sustainable Development Goal n. 2: No hunger and Goal n. 12: Responsible consumption and production. We are witnessing a growing support for methods of sustainable agricultural production, which include e.g. also agroecology, sustainable intensification, climatefriendly agriculture, or smart technologies. Sustainability means the long-term ability of food systems to provide current food security so as not to threaten the environmental, economic and social ecosystems that generate food security and nutrition for present and future generations

Purpose: Goal of the article is to point out on sustainable agriculture, food losses and waste in terms of environmental requirements in relation to food safety and nutrition. Sustainable agriculture and sustainable access to natural resources play an important role in securing current and future generations of food production.

Design: In order to obtain primary data there were 5 surveys were carried out in the Slovak republic. Surveys were carried out in agricultural enterprises, food processing enterprises, retail, distribution and catering establishments and in Slovak households in the period from September 2019 to August 2020.Based on results of the surveys article presents overall summary of obtained data.

Findings: Climate change is affecting agriculture, including lower yields and productivity, drought and water scarcity, extreme temperature stresses, lower forest productivity, weed growth and new diseases caused by viruses and foodborne diseases. All this leads to rising prices, has a negative impact on health, food security and nutrition. Increasing weather variability and natural disasters associated with climate change have multiplier effects on agricultural production, which significantly affects food trade and food consumption.
\end{abstract}

Key words: food waste, food losses, sustainability, food systems, environmental management

\section{Introduction}

Despite the urgency and severity of this global problem, there is currently no uniform definition of food waste, food loss or food waste. The most common definition is by FAO (2014) which defines food losses as a reduction in the quantity or quality of food, regardless of the causes originally intended for human 
consumption, with a reduction occurring at all stages of the food chain from harvest to harvest and ending in consumption. MARD SR (2016) also defines the term food loss, which means the amount of food that is produced for human consumption, but for various reasons is lost from the food chain. It is the difference in the quantity of food under Article 2 of Regulation No. 178/2002 at the beginning of the food chain (moment of leaving the farm) and the amount of food at the end of the food chain (use by the final consumer). Food losses can be generated before, during or after the preparation of food in households, as well as food losses occurs through activities that are also carried out by commercial establishments and catering services.

Food waste is any food, and inedible parts of food, removed from the food supply chain to be recovered or disposed, including the following destinations: composting, crops ploughed in/not harvested, anaerobic digestion, bio-energy production, cogeneration, incineration, disposal to sewer, landfill or discarded to sea but not including food or inedible parts of food removed from the food supply chain to be sent to animal feed or bio-based material/chemistry processing (Tostivint et al., 2016).

\section{Research background}

Food losses and food waste are expressed in caloric values in some studies. This caloric approach seeks to more effectively express food losses and food waste along the entire food supply chain. This concept applies the optics of "caloric efficiency" of food systems, expressing the fact that as food systems of plant and animal products proceed in the transformation of the original calories into calories intended for human consumption and how these are effectively used in the final phase of consumption. Such caloric expression of food losses was also used by the authors in their publication "Future Food Systems" (2020).

The backward or lack of infrastructure related to existing post-harvest technologies and storage structures plays an important role in food losses, which severely limits the ability of these countries to transform their agricultural production into food products that can be stored, especially for fruits and vegetables. The result of such a weak post-harvest and storage infrastructure, as well as limited transport options, cause a large volume of food waste.

Food losses and waste have a significant impact on food sufficiency. (Alexander et al., 2017). According to FAO estimates, in 2016, $13.8 \%$ of food produced was lost in the food chain, from farm levels to food storage, before it entered the commercial network (FAO 2019). This figure does not include food waste caused by consumers, which is of high value, especially in developed countries and urban agglomerations. below shows the distribution of food losses and waste along the supply chain in a world (Table 3 ). 
Table 3. Proportion of food waste at different stages of the food supply chain according to different available studies (in \%)

\begin{tabular}{|l|c|c|c|c|c|}
\hline & $\begin{array}{c}\text { FAO } \\
\text { (data } \\
\text { for } \\
\text { Europe) }\end{array}$ & $\begin{array}{l}\text { Foodspill } \\
\text { (Finland) }\end{array}$ & $\begin{array}{c}\text { FH } \\
\text { Münster } \\
\text { (Germany) }\end{array}$ & $\begin{array}{c}\text { Bio } \\
\text { Intelligence } \\
\text { Service } \\
\text { (EU) }\end{array}$ & $\begin{array}{c}\text { Fusions } \\
\text { (7RP) }\end{array}$ \\
\hline Production & 23 & $19-23$ & 22 & 34,2 & 11 \\
\hline $\begin{array}{l}\text { Processing } \\
\text { industry }\end{array}$ & 17 & $17-20$ & 36 & 19,5 & 19 \\
\hline Retails & 9 & $30-32$ & 3 & 5,1 & 17 \\
\hline Consumers & 52 & $28-31$ & 40 & 41,2 & 53 \\
\hline
\end{tabular}

Source: WRI analyse based on study Global food lossses and food waste, FAO 2011. Rím: FAO OSN: Jun 2013; http://www.mtt.fi/foodspill, 2011; https://www.fh-

muenster.de/isun/lebensmittelabfall-projekte.php, 2012; (Gustavsson et al., 2013); FUSIONS, „Estimation of food waste in Europe “, 2016.

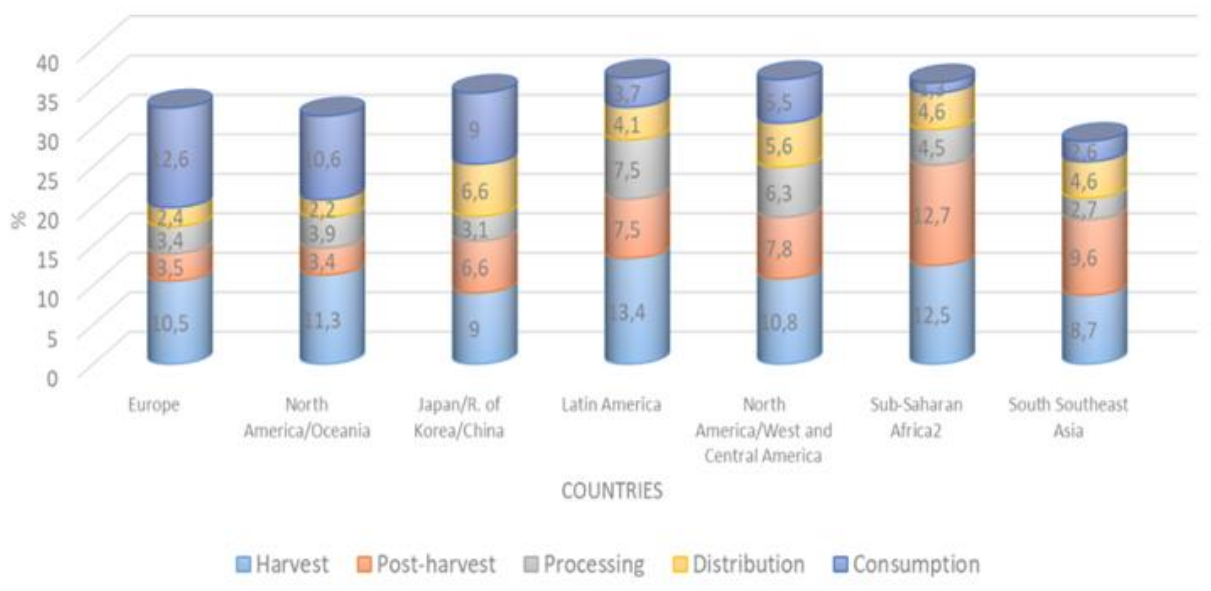

Figure 1. Distribution of the food losses and food waste along the supply chain

Source: The future of food and agriculture. Trends and challenges, 2017, FAO, p.114, ISBN 978-92-5109551-5

Food systems intersect with other systems that are directly related to sustainable development goals (SDGs) e.g. Progress towards Sustainable Development Goal 2 of Agenda 2030 "Zero hunger" directly affects Goal 3 on health and vice versa. Sustainable Development Goal 6 on access to clean water and sanitation infrastructure is essential for food production as well as for human nutrition. Goal 12 on responsible production and consumption is important for achieving sustainable food security and nutrition. Goal 13 on responsible fishing and 15 on biodiversity 
are equally directly related to Goal 2 "Zero hunger", just as aquatic and terrestrial ecosystems support food production.

According to HLPE (2014), food systems concentrate all components (environment, people, inputs, processes, infrastructures, institutions, etc.), activities related to the production, processing, distribution, preparation and consumption of food and the outputs of these activities, including social, economic and environmental results.

Sustainable agriculture and sustainable access to natural resources play an important role in securing current and future generations of food production. We are witnessing a growing support for methods of sustainable agricultural production which includes e.g. also agroecology, sustainable intensification, climate-friendly agriculture, or smart technologies. Sustainability is understood in the wider literature as an integral part of the concept of food security (Lang and Barling, 2012; Garnett, 2013; Berry et al., 2015; Béné et al., 2019) and is the central idea of policy initiatives related to sustainable development goals. Sustainability means the long-term ability of food systems to provide current food security without compromising the environmental, economic and social ecosystems that generate food security and nutrition for current and future generations (HLPE, 2020). Sustainability as a dimension of food security applies the practice of food systems that long-term respect and protect ecosystems in conjunction with the economic and social systems needed for food security and nutrition (El Bilali et al., 2017).

\section{Methodology}

Goal of the article is to point out on sustainable agriculture, food losses and waste in terms of environmental requirements in relation to food safety and nutrition. In order to meet the set goal, 5 surveys were carried out, which were realized in agricultural enterprises (45 farms), food processing enterprises (42 companies), retail, distribution and catering establishments (442 subjects) and in Slovak households (2068 households) in the period from September 2019 to August 2020. Based on results of the surveys article presents overall summary of obtained data, impact of food waste on economy, environment and society and presents initiatives which should be carried in order to improve environmental management in the Slovak republic.

\section{Food losses and trends in the development of technologies and innovative approaches}

The possibilities of reducing food losses that occur in the first stages of the food chain are largely influenced by the more sophisticated technologies used. The opposite of traditional technologies are digital technologies, which lead to increased efficiency. New plant breeding technologies, such as genome editing, are progressive compared to traditional agricultural biotechnologies, while there are concerns about their environmental and social impacts. Persistent weaknesses, such as post-harvest treatment and storage infrastructures, pose serious problems, 
including food losses and waste. In this respect, new trends in agricultural development can contribute to the conservation of natural resources.

Data driven technologies are revolutionizing almost all sectors, including agriculture and food. We are witnessing a huge amount of innovation and what we know as "digital agriculture" assists in decision-making processes on farms, including the use of inputs. This involves equipping technical equipment on farms such as tractors, harvesters and other agricultural technologies with GPS systems, satellites connected by digital sensors, the use of drones, or the application of precision agriculture, which have been used in practice for many years. (Rose and Chilvers, 2018).

An increasing number of farmers, especially in industrialized countries, are increasingly using these technologies to increase the efficiency of inputs such as energy, agrochemicals, seeds, etc. In other cases, farmers use these technologies to address labour shortages, e.g. robotic milking parlour.

Farmers in less developed countries, including small farmers, are also beginning to apply digital technologies, although there is a significant knowledge gap, so much more research will be needed in this area to be able to take advantage of these trends.

These data-driven digital technologies have a major impact on food security and nutrition, although there are still conflicting discussions about this. Proponents argue that digital technologies allow farmers to make the right decisions by using computer-assisted big data analyses that can help determine the application of more optimal doses of fertilizers, pesticides and other inputs when used efficiently in their fields.

However, critics emphasize that "technology alone" cannot solve food security and warn that the growing amount of specific data that can be transferred to large private corporations providing these technologies and related services raises important data ownership issues, and their management (Bronson and Knezevic, 2016).

Another group of experts emphasizes that these technologies are not available to poorer farmers and may further accentuate inequalities between farmers in developing and industrialized countries (Moseley, 2017).

\section{Environmental impacts of food waste and food losses - Food waste versus water waste}

In 2015, climate change was listed by the UN among the 17 sustainable development goals under number 13 - Climate protection. The sharp rise in global temperatures, rising global ocean levels, frequent weather fluctuations are all consequences of climate change. Water scarcity will multiply if this sustainable UN target is not at least partially met by 2030 . It goes without saying that average air temperatures will affect agricultural production and lead to higher water requirements for plants. Agriculture will have to prepare for such impacts of climate change by using modern irrigation systems that, with minimal abstraction, will maximize the efficiency of the water used, so that it leads to higher plant yields. Such an approach will not save farmers from drought, but when drought comes, it will not 
result in the devastating effects of hunger and a lack of healthy food and nutrition. Water consumption has doubled in the last century compared to population growth. About 4 billion people out of a total of 7.9 billion lives in conditions of severe water shortage for one month a year and at least 1.6 billion has no access to tap water.

Agriculture uses on average up to $70 \%$ of fresh water supplies. In developing countries, this figure is as high as $95 \%$. Agricultural fertilizers, pesticides and other contaminants are among the main sources of water pollution which, if not properly managed, cause significant social, economic and environmental damage.

Water is essential for every form of life, for all aspects of socio-economic development and for maintaining healthy ecosystems. While, on the one hand, there are sufficient drinking water resources from a global perspective, on the other hand, further intensive development of agriculture and industry raises serious concerns in terms of the long-term use of water resources. Water scarcity is one of the world's greatest challenges today. Therefore, the issue of water has been included among the 17 sustainable goals of the UN, which are to be met by 2030. Water is listed under the Goal No. 6 Clean water and hygiene. The priority mission of this goal is to ensure the availability and sustainable management of water and sanitation for all. Achieving this goal is very challenging, especially when we realize that for $40 \%$ of people today, clean water and sanitation are not available. This goal is closely linked to the protection of healthy ecosystems - mountains, rivers and wetlands.

Although there are sufficient supplies of drinking water in the world, more and more regions, especially in the southern hemisphere, suffer from chronic shortages. On average, agriculture requires $70 \%$ of water consumption for its production processes, in developing countries it is up to $90 \%$. Food production has increased by $100 \%$ in the last three decades. According to FAO forecasts, the volume of this food production will also need to increase by a further $60 \%$ by 2050 to meet the increased food demand of the growing human population. According to corresponding FAO research, irrigated areas are expected to support the growth of food production by $50 \%$ by 2050 , but in the interests of sustainable development, only $10 \%$ more water can be used than is currently the case. This will require the introduction of the most progressive irrigation techniques, which will ensure the most efficient use of drinking water while minimizing its consumption and achieving higher yields per hectare.

The world has 1400 mil. $\mathrm{km}$. cubic waters, but only $0.003 \%$ of this amazing amount $(45,000$ cubic kilometres) are sources of drinking water. This water is used for drinking, hygiene, agricultural and industrial production, but not all of it is ultimately used for the aforementioned purposes, due to the fact that much of this water is washed away by major floods. A huge amount of water is needed for food production. According to FAO (2009) calculations, the daily dose of food needed for one person requires 2000 to 50001 of water. Water consumption for:

- the production of one hamburger requires 24001 of water,

- the production of one egg requires 121 of water,

- the production of one three-part cup of milk requires 2001 of water,

- 701 of water is required to grow one apple,

- the production of one slice of bread requires 401 of water, 
- the production of one potato requires 251 of water,

- the production of $1 \mathrm{~kg}$ of beef requires 14000 to 150001 of water,

- the production of $1 \mathrm{~kg}$ of chicken meat requires 43251 of water,

- 1000 to 30001 of water are needed to produce $1 \mathrm{~kg}$ of grain,

- the production of $1 \mathrm{~kg}$ of lentils requires 12501 of water (Figure 2).

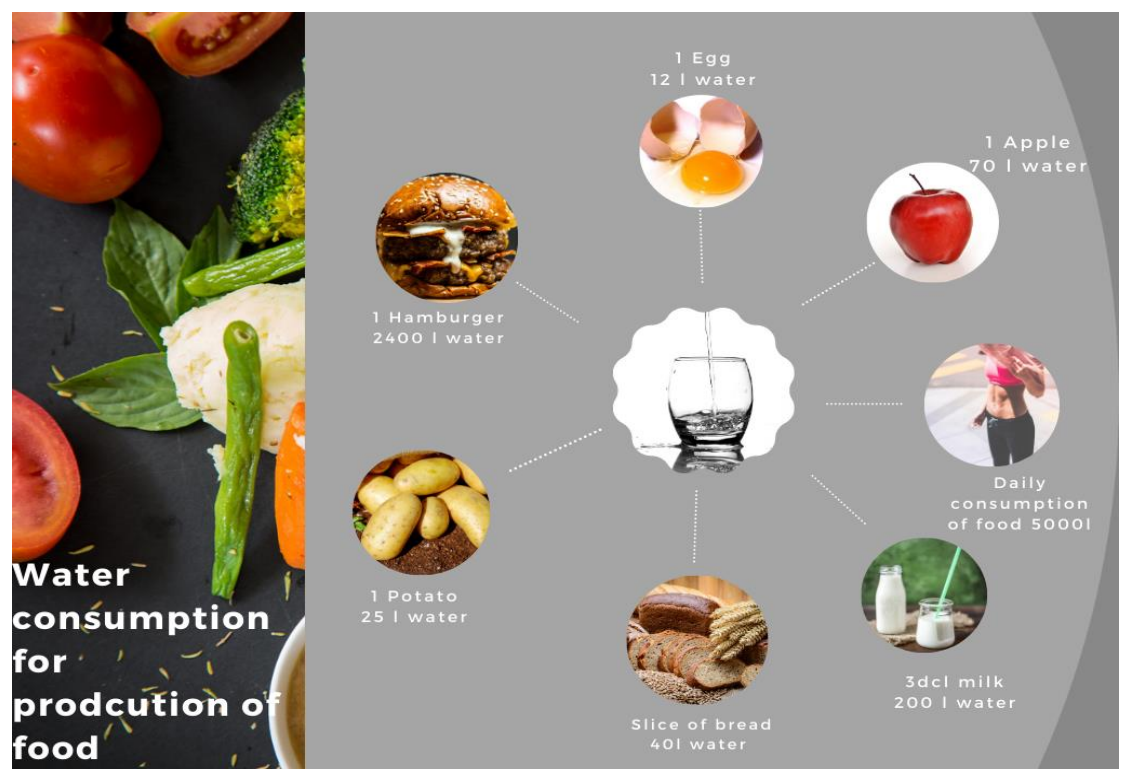

Figure 2 Water consumption for production of food

Source: Own processing based on the data from The future of food and agriculture. Trends and challenges, 2017, FAO, p.114, ISBN 978-92-5-109551-5

In food production, it should be borne in mind that water is used by plants in the field by evaporation and transpiration. The amount of water consumed varies from one plant to another depending on the place where it is grown, according to the amount of precipitation, average temperatures, the type of plant, but of course also the irrigation itself. E.g. pulses have a low trace of water consumption, as already mentioned per $1 \mathrm{~kg}$ of lentils, only 12501 of water are needed.

According to the FUSIONS project (2016), an estimated 100 million food wastes are generated each year in the EU-28. The global warming potential (GWP) of current food waste in the EU in 2011 is estimated at around 227 MT CO2 equivalent. This is $16 \%$ of the total GWP of food use in 2011. There is a global FAO study: Trace of food waste: impacts on natural resources, which emphasizes that the carbon footprint of all foods produced but not consumed is at level $3,3 \mathrm{G}$ ton $\mathrm{CO}^{2}$ Equivalent. If the results of this study were to be truly confirmed, then the issue of food waste would be the third largest source of emissions after the US and China (FAO, 2015). According to the FAO, food losses and food waste are also the cause of another 3.3 billion tons of greenhouse gases released into the atmosphere (FAO, 2014). Food waste has an impact on the environment, as its production leads to the 
loss of valuable resources such as energy, water, soil and also to the generation of greenhouse gas emissions polluting the environment (Brancoli, 2017).

The largest carbon footprint of food waste is in total cereals with $34 \%$, followed by meat and vegetables - both with a share of $21 \%$. All food waste of animal origin accounts for $33 \%$ of the total carbon footprint production, although its volume in food waste is only $15 \%$ (FAO, 2013). In terms of per capita, the average carbon footprint of food waste is $500 \mathrm{~kg} \mathrm{CO} 2$ per year. Europe, North America, along with Oceania and the industrialized part of Asia, have the largest carbon footprint per capita per year. In these areas, the carbon footprint is approximately 700 to $900 \mathrm{~kg}$ of $\mathrm{CO}^{2}$ per capita per year (FAO, 2013). This includes industrially developed and consumer-oriented countries. In these countries, the significant production of food waste is at the end levels of the food chain - supermarkets, catering facilities and households.

\section{Use of waste for the production of alternative energy sources}

The use of waste for energy purposes is an increasingly popular topic. As food waste contains a large part of usable energy and the amount of municipal waste generated by the population is increasing every day, it is necessary to recover this waste.

At present, the issue of waste in Slovakia is regulated by the following laws:

- Act 343/2012 Coll., Amending and supplementing Act no. 223/2001 Coll. on waste

At present, waste can be handed over to:

- biogas station,

- composting plant,

- Act no. 376 of 29 November 2016 amending Act of the National Council of the Slovak Republic no. 152/1995 Coll.

On food, here in the autumn of 2016 the Ministry of Agriculture and Rural Development of the Slovak Republic enforced an amendment to the Food Act in an effort to reduce food waste, which brought the possibility of donating food to charitable organizations after the expiration date.

\section{The potential of biogas and bio energy in the world}

The use of food waste would help solve global problems, for example by producing biogas. In Slovakia, about 1.5 million tons of municipal waste is produced annually, of which about 400,000 tons are organic waste, which is suitable for biogas production (RES, 2015). Compared to global municipal waste production, which is 1.3 billion tonnes per year and is expected to double to 2.6 billion tonnes by 2025 (Worldwatch Institute, 2012). Currently, the most widespread supported biofuels biodiesel and bioethanol. Biodiesel is produced mainly from vegetable oils and bioethanol from various cereals and sugar beets. These energy crops for biofuel production need to be grown on a specific area, which means that they are dependent on arable land and in some extreme cases this can lead to undesirable deforestation. 
The importance of these biofuels is growing worldwide and measures have been taken within the EU to promote them in order to reduce greenhouse gas emissions and promote cleaner transport. However, the truth is that biofuels contributed in part to the global food crisis in 2006-2009, it is estimated that they are responsible for $30 \%$ to $75 \%$ of the increase in food prices during this period (Glopolis, 2011). Biomethane or purified biogas remains an underappreciated biofuel. Biomethane has the lowest greenhouse gas emissions and the lowest energy consumption in the entire life cycle compared to other common biofuels and is produced from biomass (RES, 2015). The advantage is that biogas production is a relatively fast process. It can be used as other gaseous fuels. Unlike fossil fuels, biogas has a positive environmental impact on the environment. Careful handling does not damage the environment and it is therefore possible to create friendly conditions in the relationship between energy and the environment (EkoBonus, How do biogas plants work? An example of an interesting solution from Třebon̆, 2011). Material suitable for biogas production is organic matter, which is mostly found in agriculture, the food sector or in the breeding of livestock. There, a large amount of biological waste is generated, which can be used very efficiently to produce biogas. It is also used as a source of electricity, heat or as a fuel in transport. In addition, a secondary product in biogas production is an environmentally friendly substance (so-called digestate), which serves as a high-quality fertilizer in agriculture (EkoBonus, How do biogas plants work? An example of an interesting solution from Třeboň, 2011). Biogas is created by a natural process, which creates the formation of gases - biogas from organic matter without the supply of oxygen, due to the action of bacteria, yeast or fungi. In the wild, biogas is commonly produced at the bottom of lakes or in peatlands. The gas mixture formed consists of about two thirds of methane (known as the main component of natural gas) and one third of $\mathrm{CO}^{2}$ (CZ Biom, 2009). Basically, wherever there are people and the production of plant and animal production, there are conditions for the production of biogas.

\section{Discussion}

Food systems with food supply chains have changed significantly in recent decades and are characterized in particular by the growing distance between producer and consumer as food chains become more global. Approximately 20 to $25 \%$ of world food production is sold on international markets (D'Odorico et al., 2014). The value of the global food market has increased from 315 billion USD in 1991 to approximately 1.5 trillion in 2017 (WTO, 2018). Low- to middle-income countries accounted for about one-third of this figure.

In addition to this context, there is much debate that large-scale food-exporting countries are severely affected by the overloading of their ecosystems, in particular the impact on soil ecology. At the same time, it is argued that it is more appropriate to redistribute the environmental impacts of food production, so that there are no serious environmental encounters in the countries that export the most food. (Balogh and Jambor, 2020). In other words, the production and socio - economic conditions of developing countries need to be regulated to produce more of their own food. 
The biggest current environmental problems in Slovakia can be considered the issue of climate change, waste management, air quality and protection of habitats and species, especially in forest, meadow and wetland ecosystems (Green Strategy, 2019). Another serious challenge is the risk of biodiversity loss, which has been going on for a long time, but a significant threat is only now occurring. According to the FAO, about $75 \%$ of the loss of world plant diversity occurred in 1900 and 2000, with the largest decline around 1950. It is explained that this loss of biodiversity is due to the expansion of monoculture agriculture. The three cereals account for more than $40 \%$ of the world's caloric intake, making food diets more homogeneous (Khoury et al., 2014). 2000 breeds of domestic animals are also at risk.

\section{Conclusion}

Climate change is affecting agriculture, including lower yields and productivity, drought and water scarcity, extreme temperature stresses, lower forest productivity, weed growth and new diseases caused by viruses and foodborne diseases. All this leads to rising prices, has a negative impact on health, food security and nutrition. Increasing weather variability and natural disasters associated with climate change have multiplier effects on agricultural production, which significantly affects food trade and food consumption. While, on the one hand, food systems are affected by climate change, on the other hand, agriculture is the second largest economic polluter of greenhouse gases after the energy sector. The FAO estimates that agriculture, forestry and land use change generate one-fifth of GHG emissions. The share of food systems in global emissions is even higher due to the use of agrochemicals, cattle breeding, transport, storage, as well as processing and trade. Incorporating sustainability into the concept of food security is logical, as trends such as climate change, degradation of natural resources, as well as increasing social and economic inequality, reduce the future capacity of ecological systems to face such confrontations in the production of diverse and healthy food. It is therefore imperative of this time to ensure the cooperation of social and economic systems through regenerative methods of agricultural production, which ensure long-term food security and nutrition.

\section{References}

1. Alexander, P. et al. (2017), Losses, inefficiencies and waste in the global food system. Agricultural systems, 2017, 153: 190-200. DOI: https://doi.org/10.1016/j.agsy.2017.01.014

2. Balogh, J. M.; Jámbor, A. (2020) The Environmental Impacts of Agricultural Trade: A Systematic Literature Review. In: Sustainability, 2020, 12.3: 1152. https://www.mdpi.com/2071-1050/12/3/1152 (access: 04-03-2021).

3. BÉNÉ, Christophe, et al. When food systems meet sustainability-Current narratives and implications for actions. World Development, 2019, 113: 116-130. DOI: https://doi.org/10.1016/S0140-6736(19)31240-1

4. Berry, E. M., et al. (2015) Food security and sustainability: can one exist without the other?. In: Public health nutrition, 2015, 18.13: 2293-2302. DOI: https://doi.org/10.1017/S136898001500021X 
5. BIOM CZ (2009). Možnosti energetického využití netradičních plodin. Biom.cz http://www.biom.cz/er/odborneclanky/moznosti-energetickeho-vyuziti-netradicnich-plodin (access: 04-03-2021).

6. Brancoli, P., Rousta, K., Bolton, K. (2017). Life cycle assessment of supermarket food waste. Resources, Conservation and Recycling, 118, 39-46. DOI: https://doi.org/10.1016/j.resconrec.2016.11.024

7. Bronson, K.; Knezevic, I. (2016). Big Data in food and agriculture. Big Data \& Society, 2016, 3.1: 2053951716648174. DOI: https://doi.org/10.1177/2053951716648174

8. D'odorico, P., et al. (2014) Feeding humanity through global food trade. Earth's Future, 2014, 2.9: 458-469. DOI: https://doi.org/10.1002/2014EF000250

9. EKOBONUS. Jak fungují bioplynové stanice? Ukázkový př́íklad zajímavého řešení z Třeboně. Ekobonus.cz https://www.ekobonus.cz/jak-funguji-bioplynove-stanice-ukazkovypriklad-zajimavehoreseni-z-trebone (access: 04-03-2021).

10. El Bilali, H., et al. (2019) Food and nutrition security and sustainability transitions in food systems. Food and Energy Security, 2019, 8.2: e00154. DOI: https://doi.org/10.1002/fes3.154

11. FAO (FOOD AND AGRICULTURE ORGANIZATION OF THE UNITED NATIONS). (2014), Food Loss Assesments: causes and solutions case studies in small-scale agriculture and fisheries subsectors. Global initiative on food loss and waste reduction - Save Food. http://www.fao.org/fileadmin/user_upload/save-food/PDF/Kenya_Food_Loss_Studies.pdf (access: 04-03-2021)

12. FAO (FOOD AND AGRICULTURE ORGANIZATION OF THE UNITED NATIONS). (2019). Fifteen years implementing the Right to Food Guidelines. Reviewing progress to achieve the 2030 Agenda. Rome. ISBN 978-92-5-131821 http://www.fao.org/3/CA3129EN/CA3129EN.pdf (access: 04-03-2021).

13. FAO (FOOD AND AGRICULTURE ORGANIZATION OF THE UNITED NATIONS). (2017). The Future of Food and Agriculture- Trends and Challenges. Annual Report, 2017. http://www.fao.org/3/a-i6881e.pdf (access: 04-03-2021).

14. FAO (FOOD AND AGRICULTURE ORGANIZATION OF THE UNITED NATIONS). (2009). Water needed for food production. http://www.fao.org/assets/infographics/FAOInfographic-water-food-production-en.pdf (access: 04-03-2021).

15. FAO (FOOD AND AGRICULTURE ORGANIZATION OF THE UNITED NATIONS). (2015). Food wastage footprint \& Climate Change. UN FAO, 2015, 15-19. http://www.fao.org/3/bb144e/bb144e.pdf (access: 04-03-2021).

16. FAO (FOOD AND AGRICULTURE ORGANIZATION OF THE UNITED NATIONS). (2013) Food Wastage Footprint. Impacts on Natural Resources - Summary Report. Rome. 63 p. ISBN 978-92-5-107752-8 http://www.fao.org/docrep/018/i3347e/i3347e.pdf (access: 0403-2021).

17. FUSIONS, 2016. EU FUSIONS www.eu-fusions.org (access: 04-03-2021).

18. Garnett, T. (2013) Food sustainability: problems, perspectives and solutions. In Proceedings of the Nutrition Society. 2013, vol. 72, no. 1, p. 29-39. https://core.ac.uk/download/pdf/208213385.pdf (access: 04-03-2021).

19. Global Panel on Agriculture and Food Systems for Nutrition. (2020). Future Food Systems: For people, our planet, and prosperity. London, UK. ISBN: 978-0-9956228-6-9 https://www.glopan.org/wp-content/uploads/2020/09/Foresight-2.0_Future-FoodSystems_For-people-our-planet-and-prosperity.pdf (access: 04-03-2021).

20. Glopolis (2011). Biofuels - Fuel for Food? Prague Global Policy Institute - Glopolis http://www.palmoilwatch.net/docs/briefing-paper-biofuels-food-or-fuels.pdf (access: 04-032021).

21. HLPE (HIGH LEVEL PANEL OF EXPERTS ON FOOD SECURITY AND NUTRITION). (2014). Food losses and waste in the context of sustainable food systems. A report by the High 
Level Panel of Experts on Food Security and Nutrition of the Committee on World Food Security, Rome 117 p. http://www.fao.org/3/a-i3901e.pdf (access: 04-03-2021).

22. HLPE (HIGH LEVEL PANEL OF EXPERTS ON FOOD SECURITY AND NUTRITION) (2020). Food security and nutrition: building a global narrative towards 2030 . A report by the High Level Panel of Experts on Food Security and Nutrition of the Committee on World Food Security, Rome 2020. 112 p. http://www.fao.org/3/ca9731en/ca9731en.pdf (access: 04-032021).

23. Khoury, C. K., et al. (2014) Increasing homogeneity in global food supplies and the implications for food security. Proceedings of the National Academy of Sciences, 2014, 111.11: 4001-4006. DOI: https://doi.org/10.1073/pnas.1313490111

24. Lang, T.; Barling, D. (2012) Food security and food sustainability: reformulating the debate. In: The Geographical Journal, 2012, 178.4: 313-326. DOI: https://doi.org/10.1111/j.14754959.2012.00480.x

25. Moseley, W. G. (2017) A risky solution for the wrong problem: why GMOs won't feed the hungry of the world. Geographical Review, 2017, 107.4: 578-583. DOI: https://doi.org/10.1111/gere.12259

26. MPRV SR (Ministerstvo pôdohospodárstva a rozvoja vidieka SR - Ministry of Agriculture and Rural Development of the Slovak Republic (MARD SR) (2016), Plán predchádzania plytvaniu potravín. https://www.mpsr.sk/resources/documents/18376.docx (access: 04-032021).

27. MŽP SR (Ministerstvo životného prostredia Slovenskej Republiky - Ministry of Environemt of the Slovak Republic): Zelenšie Slovensko - Stratégia environmentálnej politiky Slovenskej republiky do roku 2030. (2019). Bratislava: Ministerstvo životného prostredia SR, 54 p. https://www.minzp.sk/files/iep/03_vlastny_material_envirostrategia2030_def.pdf (access: 04-03-2021).

28. Rose, D. Ch.; Chilvers, J. (2018) Agriculture 4.0: Broadening responsible innovation in an era of smart farming. Frontiers in Sustainable Food Systems, 2018, 2: 87. DOI: https://doi.org/10.3389/fsufs.2018.00087

29. Tostivint, C., et al. (2016). Food waste quantification manual to monitor food waste amounts and progression. BIO by Deloitte.https://library.wur.nl/WebQuery/wurpubs/fulltext/378676 (access: 04-03-2021).

30. Worldwatch Institute. (2012). Biofuels for transport: global potential and implications for sustainable energy and agriculture. Earthscan. 481 p. ISBN 9781849770590

31. WTO (WORLD TRADE ORGANIZATION). (2018) World trade statistical review 2017. World Trade Organization 2018. 213 p. ISBN 978-92-870-4624-6 https://www.wto.org/english/res_e/statis_e/wts2018_e/wts2018_e.pdf (access: 04-03-2021). 